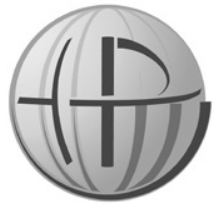

Horyzonty Polityki 2020, Vol. 11, No 35

OPEN ACCESS

\section{WOJCIECH BUCHNER}

http://orcid.org/0000-0001-8909-5242 Akademia Ignatianum w Krakowie

Wydział Pedagogiczny Instytut Nauk o Polityce i Administracji wojciechbuchner@gmail.com

DOI: 10.35765/HP.1981

\section{Władza i racja stanu w czasach Renesansu włoskiego i hiszpańskiego}

\title{
Streszczenie
}

CEL NAUKOWY: Celem artykułu jest prezentacja specyfiki myśli politycznej Renesansu w Italii i jej oddziaływania na myśl polityczną w Hiszpanii XVI stulecia.

PROBLEM I METODY B AD AWCZE: Artykuł prezentuje dwie zasadnicze zdaniem autora komponenty myśli politycznej Renesansu włoskiego: idee racji stanu oraz równowagi sił. Ukazuje ich oddziaływanie na umysły zwłaszcza florenckich humanistów Quattrocento i Cinquecento, a także analizuje wpływ na dążenia do hegemonii hiszpańskich Habsburgów. Metodą w nim zastosowaną jest historia idei.

PROCES WYWODU: Artykuł składa się z dwóch części - pierwsza poświęcona jest myśli politycznej Renesansu włoskiego, druga - analizie jej wpływu na strategie polityczne przyjęte w Hiszpanii w okresie jej hegemonii w Europie jako głównej potęgi broniącej katolickiej racji stanu.

WYNIKI ANALIZY NAUKOWEJ: Zasadniczą konkluzją płynącą z analizy jest zwrócenie uwagi na istotny dla Renesansu koncept racji stanu, który krystalizuje się w Italii w epoce przedtrydenckiej, ogniskując się głównie na polityce ograniczonej do strategii politycznych państw Półwyspu Apenińskiego. W części drugiej pojawia się teza o próbach przeszczepienia tego konceptu na Półwysep Iberyjski, gdzie jednak - w obliczu nowej sytuacji geopolitycznej po wojnach włoskich oraz odrodzenia się tomizmu - nie znajduje on ani zrozumienia, ani zastosowania. 
WNIOSKI, INNOWACJE, REKOMENDACJE: W zamyśle artykułu leży podkreślenie ważnego momentu epoki późnego Renesansu, w którym - wskutek zmiany sytuacji geopolitycznej w Europie i ewangelizacji Nowego Świata włoskie idee racji stanu oraz równowagi sił muszą ustąpić miejsca racjom wynikającym z konieczności obrony świata katolickiego przed protestantyzmem.

\title{
SŁowA KLUCzowe:
}

renesans, racja stanu, geopolityka, monarchia, republika

\author{
Abstract \\ POWER AND REASON OF STATE AT THE TIME \\ OF ITALIAN AND SPANISH RENAISSANCE
}

RESEARCH OBJECTIVE: The goal of this article is to present a specific character of the Renaissance political thinking in Italy and its influence on the Spanish political thought at XVIth century.

THE RESEARCH PROBLEM AND METHODS: The article presents two - in the opinion of author - principal components of the Renaissance political thought in Italy: the ideas of the reason of State and the balance of powers. It reveals theirs influence on the minds of the Florentine humanists of Quattrocento and Cinquecento, and analyses also theirs effect on the Spanish Habsburgs aspiration to the hegemony. The method applied is the history of ideas.

THE PROCESS OF ARGUMENTATION: The article consists of the two parts: the first is dedicated to the political thought of the Italian Renaissance, the second one - to the an analysis of its impact on the political strategies of Spain at the time of its hegemony in Europe as the main power, which defended the catholic reason of State.

RESEARCH RESULTS: The principal result of analyses is to take notice of the substantial Renaissance concept of the reason of State, which was taking shape in Italy at the epoch before the Council of Trent, and which was focused mainly on the politics limited to the political strategies of the Appenine Peninsula States. In the second part appears a thesis that there were attempts to implant this concept to the Iberic Peninsula, but - owing to the new geopolitical situation and after Italian wars and revival of Thomism - this concept could not be either understood or applicable.

CONCLUSIONS, INNOVATIONS, AND RECOMMENDATIONS: The intention of the article is to show an important moment of the epoch of the late Renaissance, when - owing to the change of geopolitical situation in Europe and to the evangelization of the New World - the Italian ideas of reason of State 
Władza i racja stanu w czasach Renesansu włoskiego i hiszpańskiego

and of balance of powers have to make room for reasons resulting from the necessity of defending the catholic world against the Protestantism.

\section{KeYwORDS:}

Renaissance, Reason of State, Geopolitics, Monarchy, Republic

I sovrani agiscono secondo la ragione ed uso degli

Francesco Guicciardini

Renesans w Italii ma tak wielkie znaczenie dla myśli politycznej późniejszych stuleci, że nie sposób go przecenić. Wydarzenia, które przyczyniły się $\mathrm{w}$ tych czasach do eksplozji niepowtarzalnego geniuszu artystycznego, wpłynęły także na oryginalny, nowatorski sposób myślenia politycznego i realistyczne postrzeganie faktów. Wielu historyków wyraża opinię, że ten zadziwiający charakter epoki polegał właśnie na współistnieniu owego geniuszu z bezwzględną i niekiedy brutalną polityką włoskich władców, odartą jawnie i świadomie z wcześniejszych standardów chrześcijańskich. W tej sytuacji czysta - by tak rzec - polityka przyjmuje kluczowy dla myślicieli i władców owych czasów charakter obrony racji stanu (ragione di stato), które to określenie znajduje wyraz właśnie u włoskich autorów doby przedtrydenckiej, ale także i później będzie ono miało znaczenie dla obrony szerzej rozumianej racji stanu hegemona habsburskiego po schizmie protestanckiej i soborze trydenckim.

Wystarczy spojrzeć na mapę ówczesnej Italii, aby się przekonać, jak skomplikowana była polityka włoska. Półwysep Apeniński obfitował we wszystkie niemal znane wówczas formy organizacji politycznej: księstwa, republiki, państwa zależne od zamorskiej metropolii. Najważniejsze z nich to księstwo Mediolanu, unikatowe w znaczeniu swej roli historycznej Państwo Kościelne, arystokratyczna Republika Wenecka (Serenissima), Florencja będąca swoistym poligonem doświadczalnym różnych form ustrojowych, wreszcie zależne od Hiszpanii Królestwo Neapolu, nie mówiąc już o wielu pomniejszych organizmach politycznych zarządzanych autorytarnie przez książęta, których władzę zwykło się określać mianem regime principesco. Poza samą Italia, pretendujące do hegemonii w Europie 
dwa wielkie i skłócone politycznie królestwa Hiszpanii Habsburgów i Francji Walezjuszy mieszały się do spraw Italii, nie mogąc zadzierzgnąć sojuszu przeciwko rosnącej w siłę Porcie Otomańskiej. Spoglądały natomiast chciwym okiem na Italię (D'Ambrosio, 2019).

W samej zaś Italii doszło do znaczących zmian geopolitycznych już we wczesnym Quattrocento. W północnej części Półwyspu następują przetasowania, które doprowadzą w konsekwencji do powstania systemu suwerennych państw regionalnych, tworzących nowe układy międzynarodowe. Średniowieczne komuny miejskie, choć w dużej mierze niezależne i autonomiczne, układają swoje stosunki według koniunktury politycznej zależnej a to od cesarstwa, a to od papiestwa (Pasierbek, 2019). Spory między gibelinami i gwelfami toczą się $\mathrm{w}$ Trecento zgodnie $\mathrm{z}$ logiką tych zależności. Tymczasem powstanie suwerennych państw tworzy nowe rodzaje układów i zmiennych koniunktur:

Jednym z tych nowych organizmów politycznych było toskańskie państwo regionalne pod panowaniem Republiki Florenckiej; i właśnie około roku 1400, w czasie walk, które wstrząsnęły do głębi północną i centralną Italia, doszło do ostatecznej przemiany w system państw regionalnych. (Baron, 1966, s. 9).

W całym tym skomplikowanym układzie geopolitycznym nie bez znaczenia była również wielka epopeja odkryć geograficznych i zamorskich zdobyczy korony portugalskiej, która po odzyskaniu części Półwyspu Iberyjskiego z rąk Maurów zainspirowała także sąsiednią Hiszpanię, tworząc zupełnie odrębny, światowy teatr działań i przenosząc konkurencję - zwłaszcza ekonomiczną, ale też kulturową - na rozległe i dotychczas nieznane obszary. W konsekwencji zmieniło to kierunek handlu europejskiego, budząc zazdrość w krajach protestanckich, gdzie nie omieszkano przedstawić wielkich hiszpańskich dokonań konkwisty i ewangelizacji w jak najbardziej ponurych barwach. Zawiść ta była wówczas bezsilna, choć w niedalekiej przyszłości miała wydać zatrute owoce w postaci czarnej legendy. Oliwy do ognia dolał tu jeszcze traktat w Tordesillas z 1494 roku, w którym papież Aleksander VI podzielił ziemię na dwie hemisfery, przyznając dalsze globalne zdobycze in spe koronom Portugalii i Hiszpanii, by zapobiec tym sposobem wrogiej konkurencji między katolickimi monarchiami. 
Niebagatelne zmiany nastąpiły również w sferze intelektualnej. Dokonały się one w dużej mierze za sprawą upadku Konstantynopola i exodusu uczonych greckich, którzy udawali się głównie do Italii, gdzie mogli rozwinąć skrzydła dzięki mecenatowi medycejskiemu, weneckiemu czy papieskiemu. I tak odkryciom geograficznym towarzyszyło w samej Europie odkrycie świata antycznego, do czego miała się przyczynić fundacja Akademii Platońskiej przez Cosima de Mediciego, jej dalszy rozkwit pod rządami Lorenza de Medici oraz intelektualnym przywództwem Marsilia Ficino. Powrócono do studiowania klasycznej greki i łaciny, a arystotelesowsko-tomistyczną scholastykę wyparły studia nad filozofią Platona.

Renesansowa myśl polityczna w Italii, zwłaszcza we Florencji, nie pojawiła się wszakże deus ex machina. Poprzedziły ją intelektualne dokonania humanistów przełomu Trecento i Quattrocento. W połowie XIV wieku znany prawnik Bartolus z Sassoferrato ukuł motto, które miało być prawniczym usankcjonowaniem powstania nowych niezależnych signorii. W uszach cesarza musiało ono brzmieć dość wyzywająco: rex in regno suo imperator. Silne tendencje decentralizacyjne przetrwały jeszcze z czasów miejskich komun i podestów, a także wskutek złych doświadczeń miast Italii w ich kontaktach $\mathrm{z}$ cesarzami niemieckimi.

Idea wolności obywatelskiej, w sposób oczywisty zwrócona przeciwko cesarskiej obecności na Półwyspie Apenińskim, dojrzewała zwłaszcza w gwelfickiej Florencji, która musiała także stawić czoła potędze księstwa Mediolanu, zarówno pod władaniem Viscontich, jak i późniejszych Sforzów. Jak pisze Hans Baron, idea ta dojrzewa w pełni w Historiae Leonardo Bruniego, znajdując ostateczny wyraz w Discorsi Machiavellego (Baron, 1966, s. 98). Wśród całej plejady ówczesnych pisarzy odznacza się także kanclerz Republiki Florenckiej Coluccio Salutati. W jego traktacie De tyranno, powstałym około 1400 roku, natrafiamy na treści, które w późniejszej fazie Renesansu odezwą się w pismach Niccolò Machiavellego i Francesco Guicciardiniego, tworząc swoiste jądro myśli politycznej oddanej obronie racji stanu państw włoskich w nadzwyczaj skomplikowanej koniunkturze politycznej ówczesnej Italii. W traktacie Salutatiego pojawia się znana wówczas dystynkcja pomiędzy tyrannus ex parte exercitii oraz tyrannus ex defectu tituli. Rozróżnienie to miało oznaczać, że można być nazwanym tyranem albo z uwagi na sam sposób sprawowania władzy, albo 
też z racji braku jej legitymizacji. Ten drugi przypadek odnosił się niedwuznacznie do postaci Juliusza Cezara, który - choć obdarzono go bezprawnie dożywotnią dyktaturą - uczynił zdaniem Salutatiego rzeczy konieczne dla ratowania Rzymu, ogarniętego przez ekscesy upadłej Republiki.

I chociaż, jak zauważa Ronald Witt, w całym swoim aktywnym życiu był Salutati obrońcą wolności republikańskich (Witt, 2001, s. 182), to jednak wspomniany traktat jest w swej zasadniczej wymowie promonarchiczny, a postać Cezara służy w nim uzasadnieniu tezy, że w sytuacjach wyjątkowych należy użyć wszelkiej władzy właśnie dla ratowania wolności - nawet wówczas, gdy zdobywa ją tyrannus ex defectu tituli. Jak wiadomo, wątek ten rozwinie $\mathrm{w}$ pełni dopiero Machiavelli, nadając mu dodatkowej wyrazistości.

Broniąc zatem wolności republikańskich poprzez odwoływanie się do historii Rzymu, florenccy pisarze przełomu Trecento i Quattrocento nie zawsze byli konsekwentni w swoich wyborach między Republiką a Cesarstwem, uosobionymi w wielkich postaciach Lucjusza Korneliusza Sulli i Cezara. Wskazywali wprawdzie na kontrast, jaki obie te postaci dzieli, aczkolwiek nadawali im nazbyt symboliczną rangę, co powodowało, że ich dyskusje przeradzały się niekiedy w spory czysto literackie. Tak było w przypadku debaty o tym, który z tych wielkich wodzów był założycielem Florencji jako rzymskiej kolonii. Pomijając wszakże ten motyw można dojść do konkluzji, że rozziew między tyranią oraz ideą wolności obywatelskich stanowi klucz do zrozumienia ówczesnej myśli politycznej we Florencji, która nadawała ton życiu intelektualnemu Renesansu. W tym kontekście Sulla miał być symbolicznym obrońcą wolności cywilnych, Cezar zaś symbolem ich upadku.

Gwelficka Florencja stała się wówczas ucieleśnieniem republikanizmu i humanizmu obywatelskiego - idei będących intelektualnym narzędziem walki z Mediolanem Viscontich. Zagrożenie ze strony Księstwa Mediolanu wymusiło na Florencji zawarcie z Wenecją układu obronnego przeciwko Giangaleazzo Viscontiemu. Układ ten jest ciekawym przykładem ówczesnych strategii politycznych w Italii, która skazana była wtedy na działania przywracające (zawsze z natury rzeczy względną i nietrwałą) równowagę sił. Potwierdza to kolejne przymierze $\mathrm{w}$ obronie florenckiej ragione di stato $\mathrm{w}$ celu zrównoważenia sił w Italii: oto bowiem, w obliczu wzrastającej potęgi 
Wenecji na terra ferma, republika ambrozjańska zawierzyła swój los condottiere Francesco Sforzy, z którym Wenecja zawarła sojusz, pomimo uprzedniej wrogości. Tym samym zerwane zostało przymierze między Florencją i Serenissimą. Tymczasem jednak Cosimo de Medici miał wykazać się przebiegłością godną prawdziwego męża stanu - przystąpił bowiem, wbrew długotrwałej tradycji Florencji, do przymierza ze Sforza, torując mu drogę do władzy w Mediolanie. Służący Medyceuszom i współczesny Machiavellemu Francesco Guicciardini wychwalał politykę Cosimy de Medici, twierdząc w swych Storie Fiorentine, a także w Dialogo del Reggimento di Firenze, że:

se cosí non si faceva e' viniziani si facevano sanza dubio signori di quello stato e successivamente in breve di tutta Italia; sí che in questo caso la libertà di Firenze e di tutta Italia s'ha a ricognoscere da Cosimo de' Medici (Guicciardini, 1974, rozdz. I).

Dzięki tym wszystkim przemyślnym zabiegom dyplomatycznym, obliczonym na obronę racji stanu poszczególnych państw i uzyskanie względnej równowagi sił, w połowie Quattrocento sytuacja polityczna w Italii zaczęła się stabilizować, co w przyniosło w efekcie zawarcie dwóch koalicji: pomiędzy Florencją i Mediolanem oraz Wenecją i aragońskim Królestwem Neapolu, które to koalicje, po przystąpieniu do układu Państwa Kościelnego i pomniejszych państw, przekształciły się w Najświętszą Ligę (Santissima Lega), tworząc względnie stabilny układ sił. I chociaż układ ten, jak pisze Hans Baron, „nie gwarantował całkowitego pokoju i nie zapobiegał sporadycznym konfliktom, to jednak zapewnił Półwyspowi pewien okres konsolidacji i względnego spokoju, który trwał dopóty, dopóki u kresu stulecia zachodnie potęgi nie dokonały inwazji Italii" (Baron, 1966, s. 400).

Później, w epoce Cinquecento Italia - jako się rzekło - staje się istotnym celem polityki zagranicznej wielkich europejskich monarchii, ale także i tutaj rozwijane są nowe koncepcje polityki w ogóle, jako dziedziny, którą traktować należy sine ira et studio - niczym przedmiot naukowego i wolnego od dywagacji moralnych badania. Wielu ówczesnych myślicieli mówiło w tym kontekście o niezmienności ludzkiej natury, co nadawało pojęciu „czystej” polityki cechę obiektywizmu, bowiem taka antropologia polityczna służyła bez wątpienia uznaniu człowieka za istotę podatną na nieodparty argument siły i obrony racji stanu. Ta niezmienność ludzkiej natury 
znajduje wyraz w życiowej strategii każdego człowieka, nade wszystko zmuszając jednak władcę do oportunizmu i badania aktualnych koniunktur:

Wszak sposób, w jaki się żyje - pisał przewrotnie Machiavelli -, jest tak różny od tego, w jaki się żyć powinno, że kto, chcąc czynić tak, jak się czynić powinno, nie czyni tak, jak inni ludzie czynia, ten gotuje raczej swój upadek niż przetrwanie; bowiem człowiek, który pragnie zawsze i wszędzie wytrwać w dobrem, paść koniecznie musi między tylu ludźmi, którzy nie są dobrymi. Otóż niezbędnym jest dla księcia, który pragnie utrzymać się, aby potrafił nie być dobrym i zależnie od potrzeby posługiwał się lub nie posługiwał dobrocią (Machiavelli, 1972, s. 189).

Znakomitą ilustrację do tego wywodu stanowią słowa potrydenckiego teoretyka racji stanu, Giovanniego Botero: Nescit regnare qui nescit simulare. Polityka staje się zatem dyscypliną autonomiczną i niezależną od moralności, nastawioną przede wszystkim na zdobycie i utrzymanie władzy. Odkryte w dobie Renesansu dzieło Tukidydesa musiało dodatkowo rozpalić wyobraźnię i dać asumpt do formułowania podobnych myśli przez tych, którzy przeczytali słynny „dialog melijski” z piątej księgi Wojny peloponeskiej. Przemożny argument siły, użyty w dialogu przez Ateńczyków przeciwko mieszkańcom wyspy Melos, jest swoistym dowodem na to, że sztuka perswazji zawodzi z chwila, gdy jej adresat unosi się honorem i traci zdrowy rozsądek. W ten sposób argument siły, ba, nawet pragmatyczne zastosowanie okrucieństwa - tak częste w przypadku Cezara Borgii - uzyskuje status równouprawnionej perswazji. O wszystkim bowiem rozstrzygać ma skuteczność. W ramach owej Machtpolitik założenie nadrzędności interesu państwa wobec interesów partykularnych każe sądzić, że oto istnieją jakieś szczególne i doraźne racje polityczne, w obliczu których zwłaszcza tradycyjna moralność chrześcijańska traci swoje znaczenie. Toteż rozdźwięk między moralnością i siła, powinnością i faktem stanowi kluczową kwestię koncepcji ragione di stato i renesansowej filozofii władzy.

Średniowieczna doktryna polityczna nakładała restrykcje na państwo i władzę świecką w imię obrony moralności chrześcijańskiej i Kościoła. Jednakże późnośredniowieczne nurty nominalizmu i koncyliaryzmu dokonały w tej strategii poważnego wyłomu. I tak na 
przykład, świecki władca czy cesarz w ujęciu Marsyliusza z Padwy czy franciszkańskiego nominalisty Wilhelma Ockhama jawi się jako postać całkowicie suwerenna i niezależna od wskazań rzymskiego Kościoła. Stąd dzieli nas już tylko krok od uznania polityki za kwestię pragmatyki i skuteczności działania - intrygi, korupcja, zdrady i zrywanie układów uchodzić wnet zaczną za normalne instrumenty realnej polityki, które powinni brać pod uwagę wszyscy mężowie stanu, by nie wystawić się na niebezpieczeństwo utraty państwa.

Byłoby jednak pewną przesadą akcentowanie jedynie tego wątku myśli politycznej w Italii. Trzeba bowiem pamiętać o tym, jak wielką finezją w dyplomacji i działaniu wykazywali się ówcześni papieże, władcy świeccy, a także wspierający ich pisarze polityczni i doradcy. Nawet papież Aleksander VI, uchodzący za człowieka niemoralnego, w oczach ludzi epoki był przecież odpowiedzialnym za Państwo Kościelne mężem stanu i znakomitym graczem politycznym. Nie bez racji zatem Jakob Burckhardt potraktował państwo i wojnę jako dzieło sztuki w swym wielkim obrazie kultury odrodzenia we Włoszech. W tym kontekście zapewne złożył on pewnego rodzaju hołd dwóm jakże różnym republikom Półwyspu Apenińskiego - Florencji i Wenecji:

W liczbie miast, które zachowały niezależność, dwa mają największe znaczenie dla dziejów całej ludzkości: Florencja, miasto ciągłego ruchu, które nam też przekazało wszystkie myśli i dążności ogółu i poszczególnych jednostek, przez trzy wieki biorących udział w tym ruchu, i Wenecja, miasto pozornego bezruchu i politycznego milczenia. Najskrajniejsze przeciwieństwa, jakie można sobie wyobrazić, i tak jedno jak i drugie z niczym na świecie porównać się nie da (Burckhardt, 1965, s. 36).

Jest rzeczą znana, że weneccy dożowie mieli związane ręce przez ciała, które kontrolowały ich poczynania, by zapobiec ewentualnej stronniczości rodów i wszelkiej próbie ustanowienia monarchii dziedzicznej. Arystokratyczna Republika Wenecka dawała światu przykład niespotykanej gdzie indziej dbałości o praworządność:

Lud był wprawdzie wykluczony z rządów, jednakże prawa oraz aparat urzędniczy i sądowniczy chroniły go i broniły skutecznie do tego stopnia, że w porównaniu $\mathrm{z}$ innymi krajami dawały one poddanym dalece lepsze gwarancje niż gdziekolwiek indziej. 
Co więcej, jak pisze dalej Alvise Zorzi, obowiązywała

równość wszystkich członków Maggior Consiglio, ciała suwerennego i principe della Repubblica, jedynego źródła wszelkiego prawa, wszelkiego stanowiska i wszelkiej władzy [...] Ani władza ekonomiczna, ani polityczna nie zapewniała członkostwa w potężnym Consiglio dei Dieci: wszystko zależało od wyniku głosowań, zgodnie z logiką mechanizmu parlamentarnego (Zorzi, 1998, s. 285).

W porównaniu z kryzysami politycznymi, nawiedzającymi raz po raz Florencję i księstwa Italii okresu Quattrocento i Cinquecento, stabilny system Serenissimy był w istocie czymś wyjątkowym. Ponadto jej bogactwa budziły zazdrość nie tylko wśród pomniejszych książąt okolicznych państewek, ale nawet papieży. Już papież Pius II sugerował, jakoby Wenecja pragnęła wskrzesić dawną potęgę Rzymu, a wtórował mu później sam Machiavelli, twierdząc że Wenecjanie „mają w zamyśle stworzenie monarchii podobnej do rzymskiej" (Zorzi, 1998, s. 289). Owa libidine di dominio, przypisywana Wenecji nie bez racji, choć - biorąc pod uwagę jej skłonność do izolacjonizmu - z pewną przesada, stała się wówczas elementem języka międzynarodowej dyplomacji, ściągając na republikę groźbę inwazji ze strony nie tylko książąt włoskich, lecz także papieża Juliusza II, cesarza Maksymiliana, króla Francji Ludwika XII, a także króla Hiszpanii. W konsekwencji, wrogowie Wenecji zawiązali w 1508 roku Ligę w Cambrai, której poczynania i zawiłe zabiegi dyplomatyczne dały niezwykle frapujący obraz polityki racji stanu. Dostarczają też poniekąd odpowiedzi na pytanie, dlaczego właśnie renesansowa Italia stała się tym terenem, gdzie rozwijano koncepcje ragion di stato, dążąc jednocześnie do zachowania równowagi sił.

Wiadomo że, pomimo zwycięstwa wojsk francuskich nad siłami weneckimi pod Agnadello, cele Ligi nie zostały ostatecznie osiągnięte, a ona sama poszła w rozsypkę. Cesarz wycofał się z gry, a Francuzi zostali przepędzeni z Italii. Było to niewątpliwą zasługą papieża della Rovere, wielkiego gracza ówczesnej sceny politycznej w Europie. Otóż papież Juliusz II zdjął ekskomunikę z Serenissimy nie rezygnując jednak z twardych warunków, które jej postawił. Tym samym wszystko wróciło poniekąd do normy, jeśli można mówić o normalności w prawdziwej kipieli ówczesnej polityki włoskiej. Tak czy inaczej osiągnięto - jak zwykle na krótko - pewien stan równowagi 
sił, której koncepcje formułowało wielu pisarzy politycznych epoki przedtrydenckiej. Ich głównym dezyderatem było pozbycie się z Italii obcych sił (francuskich, hiszpańskich, cesarskich), a wypowiedział go po odniesionym zwycięstwie nad królem Francji papież Juliusz II: Fuori barbari!

Poczynania i niezłomną konsekwencję papieża wychwalał w swym Księciu Machiavelli, choć przecież sam był wrogiem potęgi weneckiej, a Państwo Kościelne uważał za przeszkodę w zjednoczeniu Italii. W przypadku Machiavellego znane jest wszakże dialektyczne napięcie pomiędzy uznaniem doraźnych potrzeb poszczególnych książąt i koniunktur politycznych oraz patriotyczną obroną Italianità. Właśnie to napięcie tworzy szczególny klimat myśli politycznej Renesansu florenckiego, rozdartej pomiędzy realizmem politycznym Księcia i unifikacyjnymi ideami Discorsi.

Liga Cambrai była więc w Italii realizacją polityki racji stanu państw włoskich, wyrażających wolę zachowania równowagi sił; w zamyśle miała nie tylko pozbycie się z Italii obcych potęg, ale także postawienie tamy dążeniom do hegemonii w samej Italii. Doktryna i praktyka zachowania równowagi sił na Półwyspie przyświecała zwłaszcza Medyceuszom, których państwo musiało brać pod uwagę interesy Mediolanu, Państwa Kościelnego, Wenecji i Królestwa Neapolu. Ta trudna geopolityka skomplikowała się jeszcze bardziej $\mathrm{z}$ racji ingerencji w sprawy włoskie dwóch europejskich potęg, Francji i Hiszpanii, których racją stanu nie było bynajmniej zachowanie równowagi, lecz - wręcz przeciwnie - dążenie do hegemonii. Kością niezgody i zarzewiem konfliktu między tymi potęgami stało się Księstwo Mediolanu, wywalczone ostatecznie przez hiszpańskich Habsburgów, chociaż hiszpańskie wpływy na Półwyspie miały dać się we znaki także w innych regionach. Walka tych dwóch monarchii o hegemonię naruszyła kruchą równowagę sił w Italii i odsunęła w niepamięć tak drogą Guicciardiniemu doktrynę, która polegać miała - by tak rzec - na wyrównywaniu poziomów w naczyniach połączonych za pomocą lig i koniunkturalnych przymierzy. Cytując zdanie Guicciardiniego z jego dzieła Storia d'Italia, Richard Tuck wskazuje na postać Lorenza de Medici, który w opinii twórcy koncepcji równowagi sił jawi się jako ten „który dążył do utrzymania spraw państwowych w takim stanie równowagi, w którym żadna za stron nie byłaby faworyzowana" (Tuck, 1993, s. 95). Wydaje się jednak, że 
koncepcja ta zostanie później wyparta przez dążenia do hegemonii dwóch najważniejszych mocarstw europejskich - Hiszpanii i Francji. Tak czy inaczej, odtąd głównym motorem polityki racji stanu - tym razem już globalnej - stała się, zwłaszcza po zwycięstwie nad Francją Walezjuszy pod Pawia, Hiszpania Habsburgów.

W znanym eseju España invertebrada José Ortega y Gasset stwierdził, że "makiawelizm jest $\mathrm{w}$ istocie intelektualnym komentarzem mieszkańca Italii do spraw hiszpańskich" (J. Ortega y Gasset, 1959, s. 46). I chociaż stwierdzenie to grzeszy przesadą można je przyjąć cum grano salis, bowiem w czasach dominacji hiszpańskiej w Italii Cinquecento postaci takie, jak Aleksander VI Borgia, z pochodzenia Hiszpan, jak i Ferdynand Aragoński wywierali na ówczesnej polityce włoskiej i europejskiej głębokie piętno. W oczach niektórych postaci epoki ich bezwzględne działania często wywoływały nawet rodzaj niekłamanej fascynacji. $Z$ pewnością należał do nich Machiavelli, który w zawoalowanych słowach wystosował taki oto panegiryk pod adresem króla Hiszpanii, Ferdynanda:

Pewien współczesny książę, którego wymieniać nie jest dobrze, nie głosi nigdy niczego innego, jak pokoju i wierności, a jednak i drugiej rzeczy jest największym wrogiem, i gdyby obie zachował, byłby już nieraz postradał i państwo, i znaczenie (Machiavelli, 1972, s. 199).

Biorąc jednak pod uwagę niezbity fakt, iż wszyscy władcy ówczesnej Italii strzegli własnych arcana imperii, nie ma chyba powodu twierdzić, jak to czyni Ortega y Gasset, że w szczególności polityka hiszpańskich władców i zitalianizowanych Borgiów była przyczyną pojawienia się idei racji stanu w wydaniu makiawelicznym. Można natomiast przyjąć, że kontrast pomiędzy ideą ragion di stato i jej iberyjską recepcją (razón de Estado) dowodzi, jak dalece zmieniła się scena polityczna wskutek wkroczenia na nią habsburskiej Hiszpanii. Wraz z nią musiało też ulec zmianie podejście pisarzy politycznych do samej koncepcji racji stanu, która - w imieniu świata katolickiego - miała odpowiedzieć na ataki protestantyzmu. Największym zaś i najpotężniejszym wrogiem tegoż stała się w wieku XVI arcykatolicka Hiszpania. Dlatego neopogański wydźwięk idei ragion di stato w wydaniu Machiavellego czy Guicciardiniego sprawiał, że w nowej, trydenckiej scenerii politycznej ostrze tej idei zostało stępione. Nie bez racji można chyba mówić w tym przypadku o odrzuceniu samej 
neopogańskiej idei ragion di stato w Hiszpanii, pomimo toczących się wokół niej retorycznych dyskusji.

Te zaś trwały jeszcze w epoce potrydenckiej, kiedy to Hiszpania stała się duchowym przywódcą świata katolickiego. Dzieła Machiavellego krążyły jednak nieustannie po kraju, nawet po ogłoszeniu przez Piusa IV w 1564 roku indeksu librorum prohibitorum, zwanego trydenckim, gdzie Machiavelli zajął poczesne miejsce w gronie auctores primae classis. Dopiero w latach osiemdziesiątych XVI wieku jego dzieła potępiono w indeksie wydanym przez Inkwizytora Generalnego, Gasparo de Quirogę, w którego opracowaniu znaczącą rolę odegrał nieprzejednany wróg myśli florentczyka, jezuita Juan de Mariana. To jednak dowodzi, że w Hiszpanii dzieła Machiavellego dostępne były dłużej niż w Italii, a korzystał z ich doczesnej mądrości nawet infant Filip, oczywiście za przyzwoleniem ojca cesarza Karola V. „Od początków XVI wieku książki palone i zakazane [w Hiszpanii - W.B.] są niemal wyłącznie publikacjami luterańskimi" (Puigdomènech, 1988, s. 40). Pomimo to, realny wpływ renesansowej filozofii władzy oraz włoskiej idei ragion di stato na umysły pisarzy hiszpańskich wydaje się raczej nikły. Przyczyną tego stanu rzeczy nie były zatem, przez dłuższy czas, kościelne zakazy. Ważne były natomiast przyczyny natury geopolitycznej: otóż - o czym już wspominano - hiszpańska wersja razón de Estado miała i musiała mieć wymiar globalny, bowiem Habsburgowie panowali nie tylko nad swymi posiadłościami w Europie, zwłaszcza w południowej Italii, ale także nad sporą częścią Nowego Świata, co z konieczności wiązało ich pojęcie racji stanu z ideą hegemonii, sprzecznej z natury rzeczy z dawną doktryną ragion di stato, ograniczoną do obszaru Italii. Po drugie, poza względami natury czysto politycznej, w Hiszpanii odrodził się tomizm, a neoscholastyka szkoły w Salamance pod przywództwem Francisco de Vitorii zapisała ważną kartę w historii intelektualnej XVI stulecia na Półwyspie Iberyjskim. Innym pokrewnym powodem, dla którego myśl polityczna w Hiszpanii XVI wieku nie mogła wchłonąć włoskich konceptów równowagi sił i racji stanu, był właśnie ów neoscholastyczny powrót do źródeł tomizmu i teologiczno-jurydycznych ujęć problematyki politycznej w ogóle. Metodzie tej, abstrahującej od analiz historycznych i skupionej raczej na pojęciach abstrakcyjnych, obcy był zachwyt włoskich pisarzy Renesansu nad burzliwą historią pogańskiego Rzymu. Brak 
zmysłu historycznego i chęci poszukiwania w historii starożytnej przykładów dla potwierdzenia swoich tez był, jak się wydaje, jedną z cech charakterystycznych myśli dominikanów ze słynnej Escuela de Salamanca.

$\mathrm{Na}$ koniec wystarczy jeden przykład, by uświadomić sobie, jak dalece różne były w pierwszej połowie XVI stulecia sposoby myślenia o władzy politycznej w Italii i Hiszpanii. Przykładu takiego dostarcza choćby sama metoda wykładu Francisco de Vitorii z jego dzieła De potestate civili z 1532 roku. Wzorem Arystotelesa i św. Tomasza mówi on tam o trzech przyczynach wszelkiej władzy świeckiej: celowej, którą jest konieczność zaszczepiona przez samą naturę, identyfikując ją tym samym z przyczyną konieczną; sprawczej, którą stanowią prawo Boże i naturalne oraz materialnej, którą jest wola wspólnoty (Vitoria, 91, s. 6-11). Taka metoda rozumowania sprzeczna była wówczas całkowicie z postrzeganiem rzeczywistości politycznej przez pisarzy politycznych Italii Quattrocento i Cinquecento.

Można by rzec, że myśl polityczna obu półwyspów, pomimo odczuwalnej obecności hiszpańskiej w Italii, rozwinęła się w zupełnie różnych kierunkach. $W$ taki oto sposób oba sposoby postrzegania rzeczywistości uzyskały w ramach latinitas odmienny charakter, przenosząc renesansową myśl polityczną w późniejszą epokę Baroku.

\section{Bibliografia}

Albertoni, E. (1991). Storia delle dottrine politiche in Italia. Torino: Einaudi. Baron, H. (1966). The Crisis of the Early Italia Renaissance. Civic Humanism and Republican Liberty in an Age of Classicism and Tyranny. New Jersey: Princeton University Press.

Burckhardt, J. (1965). Kultura Odrodzenia we Włoszech. Tłum. M. Kreczowska. Warszawa: Czytelnik.

Castro, A. (1987). La realidad histórica de España. México: Editorial Porrúa.

Corts Grau, J. (1968). Historia de la Filosofía del Derecho. Madrid: Editora Nacional.

D'Ambrosio R. (2019). La natura del potere: una riflessione scientifica. Horyzonty Polityki, 10 (30).

Guicciardini, F. (1974). Storie Fiorentine dal 1378 al 1509. Torino: Opere.

Guicciardini, F. (1932). Dialogo e Discorsi del Reggimento di Firenze. Bari: ed. R.Palmarocchi. 
Władza i racja stanu w czasach Renesansu włoskiego i hiszpańskiego

La razón de Estado en España. Siglos XVI-XVII. (1998). Antología de textos. Madrid: Tecnos.

Machiavelli, N. (1972). Ksiaż̇ę. Wybór pism. Tłum. Zbiorowe. Warszawa: PIW.

Machiavelli, N. (1990). Historie florenckie. Tłum. K. Estreicher. Warszawa-Kraków: PWN.

Mariana, J. de (1950). Historiae de rebus Hispaniae libri XXV. Madrid: Biblioteca de Autores Españoles.

Mariana, J. de (1950). Historia general de España. Madrid: Biblioteca de Autores Españoles.

Meinecke, F. (1929). Die Idee der Staatsräson in der neueren Geschichte: München und Berlin: Oldenbourg.

Norwich, J.J. (2015). Historia Wenecji. Tłum. J. Bartoszewicz. Warszawa: WAB.

Ortega y Gasset, J. (1959). España invertebrada. Madrid: Revista de Occidente.

Pasierbek, W. (2019). Uszanowanie charakteru władzy w średniowieczu. Horyzonty Polityki, 10 (33).

Puigdomènech, H. (1988). Maquiavelo en España. Presencia se sus obras en los siglos XVI y XVII. Madrid: Fundación Universitaria Española.

Ribadeneyra, P. de (1595). Tratado de la religión y virtudes que debe tener el príncipe cristiano contra lo que Nicolás Maquiavelo y políticos de este tiempo enseñan. Madrid.

Tuck, R. (1993). Philosophy and Governement 1572-1651. Cambridge: Cambridge University Press.

Vitoria, F de. (1991). Political Writings. Cambridge: Cambridge University Press.

Witt, R.G. (2001). The De Tyranno and Coluccio Salutati's View of Politics and Roman History. W: R. Black (eds.) Renaissance Thought. Routledge: London and New York.

Zorzi, A. (1998). La Repubblica del Leone. Storia di Venezia. Milano: Rusconi.

\section{Copyright and License}

This article is published under the terms of the Creative Commons Attribution - NoDerivs (CC BY- ND 4.0) License http://creativecommons.org/licenses/by-nd/4.0/ 